\begin{tabular}{|c|c|c|}
\hline Q) & $\begin{array}{c}\text { Türkiye Tarımsal Araştırmalar Dergisi } \\
\text { dergipark.org.tr/tutad }\end{array}$ & $\begin{array}{l}\text { Turk J Agric Res } \\
\text { 2019, 6(3): 328-335 } \\
\text { (1) TÜTAD } \\
\text { ISSN: 2148-2306 }\end{array}$ \\
\hline $\begin{array}{l}\text { ÜNIVERSiTESi } \\
\text { Bilimin Siqünda }\end{array}$ & Araştırma Makalesi / Research Article & $\begin{array}{l}\text { e-ISSN: 2528-858X } \\
\text { doi: } 10.19159 / \text { tutad.619994 }\end{array}$ \\
\hline
\end{tabular}

\title{
İncir (Ficus carica L.) Genetik Kaynaklarmın Belirlenmesine Yönelik Bir Çalışma: Türkiye, Siirt Yöresi*
}

\author{
Yasin GÜL ${ }^{1}$, Koray ÖZRENK ${ }^{\text {*** }}$ \\ ${ }^{I}$ Van Yüzüncü Yll Üniversitesi, Ziraat Fakültesi, Bahçe Bitkileri Bölümü, Van, TÜRKIYE \\ ${ }^{2}$ Siirt Üniversitesi, Ziraat Fakültesi, Bahçe Bitkileri Bölümü, Siirt, TÜRKIYE
}

\begin{tabular}{ll}
\hline \multicolumn{1}{c}{ Geliş Tarihi/Received: 13.09.2019 } & Kabul Tarihi/Accepted: 19.11 .2019 \\
\hline ORCID ID (Yazar sırasıma göre / by author order) & \\
\hline (1D orcid.org/0000-0002-9189-8017 (D) orcid.org/0000-0002-6692-2337 & \\
"Sorumlu Yazar/Corresponding Author: korayozrenk@hotmail.com
\end{tabular}

Öz: Bu çalıșma, Türkiye'nin Güneydoğu Anadolu Bölgesi'nde yer alan ve incir popülasyonunun yoğunlukta olduğu Siirt ili Eruh ilçesi Mışar Ovası'nda ve Siirt Merkez ilçeye bağlı Gökçebağ beldesinde yetiştirilen yerel incir çeşitleri üzerinde yürütülmüștür. Çalıșmada, yörenin incir gen kaynakları araştırılmıș, seçilen ağaçlarda morfolojik ve fenolojik gözlemler yapılmış, toplanan meyve örneklerinde pomolojik özellikler incelenmiş ve kimyasal analizler yapılmıştır. Pomolojik ve kimyasal özellikler yönünden incelenen çeşitlerin; meyve ağırllğı $2.31-64.82 \mathrm{~g}$, ortalama meyve boyu 20.00-52.50 mm, ortalama meyve eni 20.00-55.00 mm, meyvelerin suda çözünebilir kuru madde miktarı \% 9.00-32.00, titre edilebilir asitliği \% 0.141-0.544 ve pH’s1 3.21-4.68 arasında değişim göstermiştir. Özellikle, Türkiye kurutmalık incir sektöründe ön planda olan sarılop çeşidi ve sofralık incir piyasasında önemli yeri olan Bursa Siyahı çeşidi ile benzer niteliklere sahip olduğu düşünülen genotiplerin varlı̆̆ tespit edilmiştir.

Anahtar Kelimeler: Fenoloji, Ficus carica L., incir, pomoloji, Siirt

\section{A Study to Determine Fig (Ficus carica L.) Genetic Resources: Turkey, Siirt Region}

\begin{abstract}
This study was conducted on local fig varieties in Eruh district, Mişar plain and in Gökçebağ town of the central district of Sirt province, where an extensive fig population is found, located in the Southeastern Anatolia of Turkey. In this study, the fig gene sources of the region were investigated; morphological and phenological observations were made in the selected trees, and pomological properties of the collected fruit samples were examined, and chemical analyses were performed. Fruit weight 2.31-64.82 g, average fruit length $20.00-52.50 \mathrm{~mm}$, average fruit width $20.00-55.00 \mathrm{~mm}$, watersoluble dry matter of fruits $9.00-32.00 \%$, titratable acidity $0.141-0.544 \%$ and $\mathrm{pH}$ ranged between 3.21 and 4.68 for the cultivars evaluated for pomological and chemical properties. Local genotypes with similar properties to especially sarlop (an important variety at the forefront of Turkey's dried fig sector), and Bursa siyahı (an important variety for table fig sector) were identified.
\end{abstract}

Keywords: Phenology, Ficus carica L., fig, pomology, Siirt

\section{Giriş}

İncir (Ficus carica L.), Akdeniz kıyılarının tipik meyvesidir. Bir subtropik iklim bitkisi olan incir kışları yumuşak ve yağışlı, yazları ise sıcak ve kurak geçen bölgelerde iyi verim vermektedir. Dünya Gida ve Tarım Örgütü (Food and Agriculture Organization of the United Nations,
FAO) 2014 yılı verilerine göre dünya incir üretiminde Türkiye, 300.282 tonluk üretimi ile ilk sırada olup; Türkiye'yi Misır, Cezayir ve Fas gibi ülkeler takip etmektedir (Anonymous, 2017). Türkiye'de, Doğu Anadolu Bölgesi dışında hemen hemen bütün bölgelerde incir üretimi yapılmakta; Aydın, Bursa ve İzmir gibi iller Türkiye'nin önemli üretim alanlarını oluşturmaktadır (Anonim, 2019a).

\footnotetext{
": Bu çalışma; Van Yüzüncü Yıl Üniversitesi, Fen Bilimleri Enstitüsü tarafından kabul edilen birinci yazara ait "Siirt Yöresi İncir (Ficus carica L.) Genetik
} Kaynaklarının Belirlenmesi” isimli Yüksek Lisans Tez çalışmasından üretilmiştir. 
İncirin gen merkezlerinden biri olan Güney Doğu Anadolu Bölgesi, özellikle sofralık incir bakımından gen kaynağı durumundadır (Anonim, 2019b). Küden ve Tanrıver (1997), Güneydoğu Anadolu Bölgesi'nde yöresel isimlerle anılan incir tip ve çeşitlerinin oldukça fazla olduğunu bildirmişler; araştırıcılar, yabani incirlerin Siirt ilinin güney vadilerinde, Batman, Diyarbakır, Elazığ, Gaziantep, Besni, Kahramanmaraş, Ceyhan ve Ahir Dağı'nda lokalize olduklarını, bu nedenle de, Batı Akdeniz ve Güneydoğu Anadolu bölgelerinin özellikle taze incir çeşitleri için başlıca genetik kaynak olduğunu rapor etmişlerdir.

Kültür incirlerinde dişi çiçeklerle erkek çiçekler, iki cinsi temsil eden erkek incirlerle, dişi incirler üzerinde ayrı ayrı ağaçlarda bulunmaktadır. Genel olarak, bu şekilde dioik olan meyve türlerinde tozlanma, rüzgârlarla (anemophyl) olduğu halde incirlerde erkek ve dişi çiçeklerin, incirin kapalı bir şekilde bulunan çiçek kılıfı (receptacle) içerisinde bulunmas1, rüzgârlarla tozlanmaya olanak sağlamamaktadır. Bundan dolayı, kültür incirlerinin, meyve bağlayabilmeleri için zorunlu olarak döllenmeye ihtiyaç gösterenlerde, döllenmeye ilek sineği (Blastophaga psenes) denilen ve erkek incirlerle ortak yaşam halinde yaşayan bir böcek aracı olmaktadır. Bununla birlikte bazı tip incir çeşitleri de vardır ki, döllenmeden, partenokarpi yoluyla meyve verebilir. Bazı tip incirlerde orta bir aşamayı oluşturarak ilekleme olmadan az miktarda meyve tutarlar (Özbek, 1978). Güneydoğu Anadolu Bölgesi ve Siirt'te yetişen incirler de partenokarpi yoluyla meyve vermektedir.

Beslenme bakımından, incir ham ve indirgen lif, mineral ve polifenoller bakımından mükemmel bir besin kaynağıdır. Sodyum içeriği düşüktür ve yağ ile kolesterol içermemektedir (Vinson, 1999). Ayrıca, incir önemli miktarda, vitamin, amino asit, şeker ve antioksidan bileşikleri içermektedir (Çalışkan ve Polat, 2011).

Siirt ilinin iklim özellikleri dikkate alındığında, incirin ekolojik istekleri yönünden $\operatorname{arad1ğ} 1$ bütün optimum koşullara sahip olduğu görülmektedir. Türkiye İstatistik Kurumu'nun 2016 yılı verilerine göre (Anonim, 2019a); Siirt ilinde toplam incir üretimi 118 ton olup; bu miktarın yaklaşık 44 tonu Aydınlar ilçesinde üretilmekte, bunu 36 ton ile Merkez ve 23 ton ile Eruh ilçesi izlemektedir. Siirt ili kapsamında 2016 yılı değerlerine göre toplam meyveliklerin alanı 223 dekar, toplam meyve veren yaştaki ağaç sayısı 16.857 adet olup, 5.668 adet meyve vermeyen yaşta ağaç bulunmaktadır. Ağaç sayısı bakımından 7.000 adet meyve veren yaştaki ağaç sayısıyla Aydınlar ilçesi birinci sırada yer alırken, bu ilçeyi ikinci sırada 6.825 adet ile Merkez ve üçüncü sirada 1.465 adet ile Eruh ilçelerinin izlediği görülmektedir. Ağaç başına ortalama verim ise $8.3 \mathrm{~kg} \mathrm{ağaç}^{-1}$ 'tır (Anonim, 2019a).

İncir çeşit veya tipleri bakımından zengin olan Türkiye'de, incirin gen merkezlerinden biri olan Güneydoğu Anadolu Bölgesi'nde ne yazık ki incirle ilgili araştırma çalışmaları yok denecek kadar azdır. Siirt ilinde özellikle Eruh ilçesinde karışık meyve bahçelerinde dağınık şekilde yetiştirilen binlerce incir ağacı bulunmaktadır. Yörede, kapama incir bahçe sayısı yok denecek kadar az olsa da, farklı özelliklerde meyve veren incir ağaçları bulunmaktadır.

Bu çalışmada Siirt ili ve ilçelerinde doğal olarak yetişen mahalli incir genotiplerinin pomolojik ve morfolojik olarak tanınması, incir yetiştiriciliğine katkıda bulunulması amaçlanmış ve yörede incir yetiştiriciliğinin özendirilmesi de hedeflenmiştir.

\section{Materyal ve Yöntem}

Bu çalışma, 2011-2012 yılları arasında Siirt ili Eruh ilçesinde, incir populasyonunun yoğunlukta olduğu Mışar Ovası'ndaki köylerin karışık meyve bahçelerinde ve Siirt Merkez Gökçebağ beldesinde yürütülmüştür. İncir populasyonlarının yoğun olduğu bölgede arazi survey çalışması yapılarak 54 genotip belirlenmiş; bu genotiplerin bazı morfolojik, fenolojik, pomolojik ve kimyasal özellikleri saptanmıştır.

Çalışma karışık meyve bahçeleri üzerinde rastgele seçilen incir ağaçları üzerinde yapılmıştır. Çalışmada yerel incir çeşit ve tiplerinin varlıkları araştırılarak, üzerinde çalışılacak meyve bahçeleri belirlenmiş ve her birine genotip numarası verilmiştir. Karışık meyve bahçelerinden alınan yerel incir çeşitlerinin kodlanmasında il plaka kodu, ilçenin ünsüz harfleri ile genotipe ait numara sıralaması kullanılmıştır (Örneğin, 56 ERH 01).

Seçilen incir ağaçları Mart ayının son haftasından itibaren belirli periyotlarla gezilerek fenolojik gözlemler yapılmıştır. Çalışmanın yürütüldüğü ağaçlarda fenolojik özellikler olarak ilk yapraklanma zamanı, meyve doğuş zamanı, meyve olgunlaşma zamanı, derim süresi ve hasat tarihleri tespit edilmiştir. Fenolojik gözlemler; Eroğlu (1982), Aksoy (1991), Cebeci (1993), Küden ve ark. (1995), Anonymous (2003) ve Çalışkan ve Polat (2007)'a göre belirlenmiştir.

Belirlenen yerel incir genotiplerinin bulunduğu yer, köy adı, taşınmazın mevkii tespit edilmiş, ağaçların tahmini yaşı, ağacın verimi ve periyodisite durumu, ağacin taç genişliği ile yüksekliği, ağacın gelişme kuvveti, ağacın habitusu gibi morfolojik özellikleri de sübjektif olarak tespit edilmiş ve genotip numarası kayıt altına alınmıştır. 
Siirt ili Eruh ilçesi ve Gökçebağ beldesi ekolojik koşullarında doğal olarak yetişen incir genotiplerine ait bahçelerde, hasat döneminde her ağaçtan rastgele olgunlaşmış 10 adet meyve örneği alınmış ve toplanan örnekler viyoller ile laboratuvar ortamına getirilmiştir. Bu örneklerde meyve ağırlığı (g), meyve eni (mm), meyve boyu (mm), meyve şekil indeksi, meyve kabuk rengi, meyve kabuk kalınlığ1, meyve kabuğunun soyulma durumu, meyve kabuk dayanıklılığı, çekirdek iriliği, çekirdek miktarı, ostiolum açıklığı, çatlama durumu, tat, meyve pulp rengi, $\mathrm{pH}$, suda çözünebilir kuru madde (SÇKM, \%) ve titre edilebilir asitlik (TEA, \%) gibi pomolojik ve kimyasal özellikler Eroğlu (1982), Karaçalı (1990), Aksoy (1991) ve Anonymous (2003)'a göre belirlenmiştir.

Kalite açısından genotiplere ait özeliklerin değerlendirilmesi: Değerlendirmeye, sofralık incir türleri için önemli bulunan özellikler alınarak ve önem derecelerine göre toplamlar 100 olacak şekilde her birine göreceli puanlar verilmiştir. Aksoy (1991), tartıli derecelendirme sisteminden yararlanarak hesaplamalar yapılmıştır. Tartılı derecelendirme yöntemine göre yüksek puan alanlar belirlenmiştir.

Her özellik bakımından genotiplerin aldıkları sınıf puanı ile o özelliğin göreceli puanı çarpılarak genotipin incelenen özellik bakımından aldığı puan hesaplanmıştır. Daha sonra incelenen her özellik için genotiplerin aldıkları puanlar toplanarak genel kalite puanı belirlenmiştir. En yüksek puanı alan genotipler kaliteli sofralık incir olarak kabul edilmiştir.

\section{Bulgular ve Tartışma}

\subsection{Fenolojik özellikler}

Çalışmanın yürütüldüğü bahçelerde fenolojik özelliklerin belirlenmesi amaciyla 2011-2012 yılları arasında gözlemler yapılmıştır. Fenolojik gözlemler y1llara göre farklılık göstermemiştir. Buna göre, 2012 yılında; ilk yapraklanma 10 Nisan25 Nisan, meyve doğuş zamanı 10 Nisan-20 Mayıs, meyve olgunlaşma başlangıcı erken olarak 30 Temmuz-10 Ağustos, geç olarak 10 Ağustos-30 Ağustos, derim sürelerinin en kısa 25-40 gün (orta), 40-60 (uzun) ve 60 günden fazla (çok uzun) olduğu gözlemlenmiştir. Çalışmada, 2012 yılında hasat 05 Ağustos-15 Eylül tarihleri arasında yapılmıştır.

Can (1993), Ege Bölgesi koşullarında 1991 yılında yaptığı araştırmada incirde, en erken yapraklanmanın 28-29 Mart'ta ve en geç ise 7-10 Nisan'da oluştuğunu bildirmiştir. Başka bir araştırmada ise, en erken yapraklanmanın 23-25 Mart'ta ve en geç ise 7-10 Nisan'da gerçekleştiği saptanmıştır (Ilgın ve Küden, 1997). İlk yapraklanma yönünden yapılan değerlendirmede gerek bölgemizde ve gerekse diğer araştırmacıların denemelerini yürüttükleri yerlerde, en erken ve en geç yaprak açan genotip ve çeşitler arasında yaklaşı 15-25 günlük bir sürenin olduğu görülmektedir.

Ilgın (1995) yaptığ 1 çalışmada, seçtiği tip ve çeşitlerin derim sürelerinin 25-40, 40-60 ve 60 günden fazla olmak üzere 3 farklı zaman periyodunda gerçekleştiğini bildirmiştir. Ayrıca en erken olgunlaşma başlangıc1 20-30 Temmuz ve en geç olgunlaşma ise 15-30 Ağustos tarihleri arasında gerçekleştiğini rapor etmiştir. Özkaya (1997), 24 incir tipinin 25-40 gün içinde hasat edildiğini, 12 tipin 40-60 günde, 4 tipin ise 60 günden daha uzun sürede derimlerinin yapıldığını açıklamıştır.

$\mathrm{Bu}$ çalışmada en erken yapraklanmanın 10-15 Nisan'da ve en geç 15-20 Nisan'da, en erken meyve doğuşunun 05-10 Mayıs'ta, en geç meyve doğuşunun 15-25 Mayıs'ta, meyve olgunlaşma başlangıcının 20-30 Temmuz ile 01-15 Ağustos tarihleri arasında, genotiplerin derim sürelerinin 38 adedinde 25-40 gün, 15 adedinde 40-60 gün ve 1 adedinde ise 60 günden fazla olmak üzere 3 periyotta gerçekleştiği gözlemlenmiştir. Yapılan çalışmada meyve hasat tarihinin bölgede 20-30 Temmuz ile 10-15 Eylül tarihleri arasında gerçekleştirildiği tespit edilmiştir.

Seçilen genotipler ile ilgili elde edilen bulgular yapılan diğer araştırma bulguları ile benzer sonuçlar oluşturmuştur. Diğer bölgeler ile aralarındaki farklar ekolojik faktörler, çeşit özelliği ile iklim koşullarına bağlı olarak değişkenlik gösterebilmektedir.

\subsection{Morfolojik özellikler}

Çalışmanın yürütüldüğü bahçede morfolojik özelliklerin belirlenmesi amacıyla 2011-2012 yılları arasında iki yıl süreyle ölçümler yapılmıştır. Çalışmada, 2011 yılında 27 gün, 2012 yılında 19 gün aralıklarla morfolojik ölçümleri yapılmış; 17 Temmuz 2011 tarihi itibarıyla yapılan ölçümlerde periyodisitenin olmadığ 1 ve ağaçların tahmini 10-25 yaş aralığında olduğu tespit edilmiştir.

İncir ağaçlarının şekli (habitusu) değerlendirmesinde örnek alınan ağaçların; çok dik, dik, yayvan, çok yayvan ve sarkık, genel olarak da yayvan taç gelişimi gösterdikleri belirlenmiştir. Subjektif gözlemlerle ağaçların genel olarak orta kuvvette gelişme gösterdikleri saptanmıştır. Genotiplerin 11 adedinin orta, 36 adedinin iyi ve 7 adedinin çok iyi verime sahip olduğu tespit edilmiştir. 


\subsection{Pomolojik özellikler}

Meyve ağırlığl: Meyve ağırlığı 2.31 g (56-ERH32) ile 64.82 g (56-MRK-05) arasında değişmiş olup, genotiplerin ortalama meyve ağırlığ $25.33 \mathrm{~g}$ olarak saptanmıştır.

Eroğlu (1982), Ege Bölgesi’nden seçilen erkek incir genotiplerinde meyve ağırlığı değerlerinin 1980 yılında $11.00-71.75 \mathrm{~g}$ arasında, 1981 yılında 11.20-43.10 g arasında değişim gösterdiğini belirtmiştir. Özeker ve İsfendiyaroğlu (1998), Çeşme ilçesindeki yürütmüş oldukları seleksiyon çalışmasında, sofralık 12 incir tipinin ortalama meyve ağırlıklarını 30.00-90.00 g arasında belirlemişlerdir. Gözlekçi ve ark. (1999), Ege Bölgesi'nden selekte edilen Bardacık, Beyaz Orak, Bursa Siyahı, Karabakunya, Sarılop, Sultan Selim ve Yeşilgüz incir çeşitlerinin Antalya ekolojik koşullarındaki meyve verim ve kalitesini belirlemek amacıyla 1995-1998 yılları arasında yürütmüş oldukları çalışmada 7 çeşidin ortalama meyve ağırlıklarını $43.93 \mathrm{~g}$ ile $86.84 \mathrm{~g}$ arasında saptamışlardır. Khadivi-Khub ve Anjam (2014), İran'da yetiştirilen erkek incir genotiplerinde meyve ağırlığı değerlerini 1.52-38.12 g arasında saptamışlardır.

$\mathrm{Bu}$ çalışmadan elde edilen meyve ağırlığı değerleri, genel olarak araştırıcıların belirtmiş oldukları değerler arasında yer almıştır. Gözlemlenen farklılıkların, bitkilerin genetik özellikleri yanında, iklim ve bakım koşullarının farklı olmasından kaynaklandığı söylenebilir.

Meyve eni: Meyve eni en düșük $20.0 \mathrm{~mm}$ (56 ERH 07), en iri ise $55.0 \mathrm{~mm}$ (56 MRK 05) olup, genotip ve çeşitlerin ortalama meyve eni $37.5 \mathrm{~mm}$ olarak saptanmıştır.

Türkiye'de meyve eni ile ilgili incir çeşit ve tiplerinde yapılan araştırma sonuçları incelendiğinde; Eroğlu (1982) Ege Bölgesi'nde 33.16-54.94 mm (1980 y1l1) ve 35.99-56.61 mm (1981 y1lı), Kaşka ve ark. (1990) 33.00 mm (Beyaz Seyhan)-59.10 mm (Kuş İnciri), Aksoy ve ark. (1992) 41.32 mm-52.57 mm, Aksoy ve Anaç (1995) 36.70 mm-53.07 mm, Küden ve ark. (1995) 37.60 mm (Mor-4)-64.10 mm (01-ìN-05), Koyuncu (1998) $24.40 \mathrm{~mm}-43.60 \mathrm{~mm}$, Bostan ve İslam (1999) 42.0 mm-51.0 mm, Gözlekçi ve ark. (1999) 39.08 mm (Sultan Selim)-56.33 mm (Bursa Siyahı), Karadeniz (2003) $40.21 \mathrm{~mm}-66.50 \mathrm{~mm}$ ve KhadiviKhub ve Anjam (2014) İran'daki 53 erkek incir genotipinde meyve eninin 19.00-34.70 mm arasında değişim gösterdiğini bildirmişlerdir. Araştırmamızdan elde edilen meyve eni değerlerinin literatürdeki bu bulgular ile benzerlik gösterdiği söylenebilir.
Meyve boyu: Meyve boyu $20.0 \mathrm{~mm}$ (56 ERH 07) ile $52.5 \mathrm{~mm}$ (56 MRK 05) arasında değişiklik göstermiş olup, genotip ve çeşitlerin ortalama meyve boyu $34.6 \mathrm{~mm}$ olarak saptanmıştır.

Türkiye'nin farklı ekolojilerinde yürütülen araştırma bulguları incelendiğinde, meyve boyu değerlerinin $22.00 \mathrm{~mm}$ ile $72.00 \mathrm{~mm}$ arasında değişim gösterdiği rapor edilmiştir (Eroğlu, 1982; Kaşka ve ark., 1990; Aksoy ve ark., 1992; Aksoy ve Anaç, 1995; Küden ve ark., 1995; Koyuncu, 1998; Bostan ve İslam, 1999; Gözlekçi ve ark., 1999; Karadeniz, 2003). Khadivi-Khub ve Anjam (2014) ise, İran'daki 53 erkek incir genotipinde meyve boyunu 25.30-55.60 $\mathrm{mm}$ arasında tespit etmişlerdir. Araştırmamızdan elde edilen meyve boyu değerlerinin literatürdeki bu bulgular ile benzerlik gösterdiği söylenebilir.

Meyve şekil indeksi (En/Boy): Meyve şekil indeksi 0.83 (56 ERH 17)-1.20 (56 ERH 04) arasında olduğu saptanmış; 30 adet genotip basık oval, 21 adet genotip küresel ve 3 adet genotip ise uzun oval olduğu belirlenmiştir.

Kahramanmaraş'ta yapılan bir çalışmada (Ilgın, 1995), Abbas çeşidinin tüm tiplerinde meyve indeksinin 1.20-1.40 arasında değiştiği ve bu tiplerin basık boyunlu şekle sahip iken, Bardak çeşidinin 462-7 tipi dışındaki öteki tiplerin meyve şekil indeksi 1.00-1.10 arasında olduğu ve bu meyvelerin küresel boyunlu şekle sahip oldukları; 3 tipin basık boyunsuz şekle sahip oldukları halde öteki tiplerin ise basık boyunlu veya küresel boyunlu oldukları belirlenmiştir.

Çekirdek iriliği, çekirdek miktarl ve meyve kabuk rengi: Hepaksoy ve ark. (2004), incir çeşitlerinin meyve özelliklerini belirlemek amacı ile meyvedeki çekirdek miktarı az, orta, çok şeklinde ve çekirdek büyüklüğü de küçük, orta ve iri olarak gruplara ayırmışlar, çekirdek miktarlarının ve iriliklerinin çeşitlere göre değiştiğini bildirmişlerdir. Çeşitlerin meyve kabuklarının renklerini görsel olarak belirlenerek sarımsı kahve, açık kırmızı, kırmızı, koyu kırmızı, vişne, pembe, koyu pembe, açık kahve ve kirli siyah renkleri olmak üzere 9 gruba ayırmışlardır.

Genotiplerin çekirdek iriliğinin genellikle orta büyüklükte, çekirdek miktarının genellikle orta yoğunlukta olduğu tespit edilmiştir. Ayrıca genotiplerin 10 adedinin sar1, 28 adedinin sarımtırak yeşil, 6 adedinin mor ve 10 adetinin koyu mor meyve kabuk rengine sahip olduğu gözlemlenmiştir.

Seçilen tiplerin çekirdek irilikleri ile ilgili bazı araştırmacılar değişik çalışmalar yapmışlardır. Küden ve ark. (1995), Çukurova Bölgesi'ne 
önerilebilecek bazı incir çeşit ve klonlarının saptanması amacıyla yaptıkları çalışmada ortalama çekirdek iriliği bakımından 4'ünün küçük, 5'inin orta ve 7'sinin ise iri olduğunu saptamışlardır. Ilgın (1995), yaptığı araştırmada çekirdek iriliğinin 5 tip veya çeşitte küçük, 32 tipte veya çeşitte orta ve 15 tip veya çeşitte ise büyük olduğunu saptamıştır. Çekirdeklerin sayıları ve irilikleri meyve kalitesi üzerinde etki yapmaktadır.

Az ve küçük miktarda çekirdeğe sahip olan çeşitler daha çok beğenilen ve talep edilen çeşitlerdir (Arendt, 1972). Çekirdek iriliği bakımından yaptığımız araştırmadan elde edilen bulgular yukarıdaki araştırıcıların çalışmalarına benzerlik göstermektedir.

Meyve kabuk kalınlığl: Kabuğun dayanıklı bir yapısının olup olmadığı sübjektif gözlemlerle belirlenmiştir. Buna göre, 56 ERH 13, 56 ERH 17 ve 56 ERH 23 genotiplerinin kabuklarının az dayanıklı, diğer incir genotiplerinin ise dayanıklı kabuk yapısına sahip oldukları tespit edilmiştir.

Meyve kabuğunun soyulma durumu: Araştırmalarda belirlenmiş olan incir genotipleri üzerinde yapılan incelemelerde meyve kabuğunun soyulma durumuna göre; 56 ERH 01 ile 56 ERH 10 çeşitlerinin meyve kabukları zor, 56 ERH 10, 56 ERH 24, 56 ERH 44 ve 56 ERH 45 orta soyulma özelliğine sahip olduğu, diğer tip ve çeşitlerin ise kolay soyuldukları gözlemlenmiştir.

Ostiolum açıklığ ve çatlama durumu: Genotiplerin 46 adetinin kapalı, 5 adetinin kısmen açık, 3 adetinin ise açık ostiolum açıklığına sahip olduğu gözlemlenmiştir. Genotiplerin ostiolumunda çatlama durumunun 4 adedinde kısmen, 49 adedinde olmadığ ve 2 adedinde çatlama durumunun olduğu gözlemlenmiştir.

Meyve pulp rengi: Genotiplerin 25 adedinin kırmızı, 5 adedinin krem ve 24 adedinin ise pembe pulp rengine sahip olduğu gözlemlenmiştir.

Tat: İncelenen 54 genotip içinde, 20 genotip çok tatlı, 25 genotip tatlı ve 9 genotipin ekşimtırak meyve tadına sahip olduğu belirlenmiştir.

\subsection{Kimyasal özellikler}

Suda çözünebilir kuru madde (SÇKM): Genotiplerde yapilan kimyasal analizler sonucu, SÇKM'nin \% 9.00 (56 ERH 41)-32.00 (56 ERH 48) arasında değiştiği belirlenmiştir.

SÇKM değerlerini; Aksoy ve ark. (1992) 34 çeşitle yürütmüş oldukları araştırmada \% 16.5027.00, Aksoy ve Anaç (1995) Sarılop meyvelerinde \% 19.37-29.40, Ilgın ve Küden (1997) \% 17.739.33 Gözlekçi ve ark. (1999) \% 15.80-29.50 arasında değiştiğini belirlemişlerdir. SÇKM yönünden araştırmamız sonuçları ile literatürdeki bu bulgular arasındaki farklılığın iklim koşullarındaki farklılıklardan meydana geldiği düşünülmektedir.

Titre edilebilir asitlik (TEA): TEA değerinin \% 0.141 (56 ERH 42)-0.544 (56 ERH 46) arasinda değiştiği tespit edilmiştir.

Aksoy ve ark. (1992), Türkiye'nin değişik bölgelerinden selekte edilen 34 çeşitle Aydın'da kurulmuş olan incir bahçesinde yürütmüş oldukları araştırmada, çeşitlerin toplam asit miktarının \% 0.105 ile \% 0.700; Aksoy ve Anaç (1995), Sarılop incir bahçelerinde kireç uygulamalarının yaprak ve meyve bitki besin maddeleri kapsamlar1, sürgün gelişmesi ve meyve kalitesi üzerine etkilerini belirlemek amacıyla İzmir'de yürütmüş oldukları araştırmalarında, 3 ayrı bahçedeki Sarılop meyvelerinin meyve asitliğinin \% 0.14 ile \% 0.31 ; Ilgın ve Küden (1997), Kahramanmaraş ilinde yetiştirilen sofralık incirler üzerine yürütmüş oldukları seleksiyon çalışmalarında, meyve kalite özelliklerine göre seçmiş oldukları 52 tipin meyvelerinin titre edilebilir asit oranının \% 0.04 0.68 arasında değiştiğini saptamışlardır. İncir tip ve çeşitleriyle yapılan diğer bazı araştırmalarda da titre edilebilir asit miktarının \% $0.06-0.42$ arasında değişim gösterdiği belirlenmiştir (Koyuncu, 1998; Özeker ve İsfendiyaroğlu, 1998; Bostan ve İslam, 1999; Gözlekçi ve ark., 1999). Araştırmamızda tespit etmiş olduğumuz $\% \quad 0.141-\% \quad 0.544$ aralığındaki titre edilebilir asit verileri ile daha önceki araştırma verilerinin benzerlik gösterdiği söylenebilir.

pH: Çalışmada, incir genotiplerinin $\mathrm{pH}$ değerlerinin 3.21 (56 ERH 41)-4.68 (56 ERH 16) arasında değişim gösterdiği saptanmıştır.

İncir ile yapılan araştırmalarda meyvede $\mathrm{pH}$ değerlerinin 2.01 ile 5.90 arasında değişim gösterdiği (Aksoy ve ark., 1992; Koyuncu, 1998; Özeker ve İsfendiyaroğlu, 1998; Bostan ve İslam, 1999; Karadeniz, 2003) ve literatürlerdeki bu bulguların araştırmamız sonuçları uyumlu olduğu görülmüştür.

\section{5. İncelenen genotiplerin değiştirilmiş tartılı derecelendirme puanları}

Seçilen genotiplerin değiştirilmiş tartılı derecelendirme yöntemine göre genel kalite açısından değerlendirildiğinde; 940 puan ile "56 ERH 42" (Tefari) genotipinin ilk sirada olduğu, bunu 790 puan ile "56 ERH 03" (Bacani), "56 ERH 19" (Bacani), "56 ERH 26" (Behnati), "56 ERH 27" (Behnati) ve "56 ERH 30" (Behnati), 780 puan ile "56 MRKZ 05" (Teğte) genotiplerinin izlediği saptanmıştır. Araştırmada, 360 puan ile "56 ERH 10" genotipi son sırada yer almıştır (Tablo 1). 
Tablo 1. Değiştirilmiş tartılı derecelendirme yöntemine göre genotiplerin puanlarının hesaplanması

\begin{tabular}{|c|c|c|c|c|c|c|c|c|}
\hline Genotip no & MA & MŞİ & KÇ & KSD & $\mathrm{OA}$ & SÇKM & TEA & Toplam puan \\
\hline 56 ERH 01 & 60 & 90 & 100 & 0 & 50 & 30 & 60 & 390 \\
\hline 56 ERH 02 & 0 & 150 & 100 & 100 & 50 & 150 & 60 & 610 \\
\hline 56 ERH 03 & 120 & 150 & 100 & 100 & 50 & 150 & 120 & 790 \\
\hline 56 ERH 04 & 0 & 90 & 100 & 100 & 50 & 90 & 60 & 490 \\
\hline 56 ERH 05 & 0 & 90 & 100 & 100 & 50 & 30 & 120 & 490 \\
\hline 56 ERH 06 & 60 & 150 & 100 & 100 & 50 & 60 & 120 & 580 \\
\hline 56 ERH 07 & 180 & 150 & 100 & 60 & 50 & 30 & 60 & 630 \\
\hline 56 ERH 08 & 180 & 120 & 100 & 100 & 50 & 60 & 60 & 670 \\
\hline 56 ERH 09 & 60 & 90 & 100 & 100 & 50 & 150 & 120 & 670 \\
\hline 56 ERH 10 & 0 & 120 & 100 & 0 & 50 & 30 & 60 & 360 \\
\hline 56 ERH 11 & 0 & 150 & 100 & 100 & 50 & 60 & 150 & 610 \\
\hline 56 ERH 12 & 0 & 90 & 100 & 100 & 50 & 150 & 60 & 550 \\
\hline 56 ERH 13 & 0 & 150 & 100 & 100 & 50 & 150 & 60 & 610 \\
\hline 56 ERH 14 & 120 & 150 & 100 & 100 & 50 & 60 & 60 & 640 \\
\hline 56 ERH 15 & 0 & 150 & 100 & 100 & 50 & 150 & 120 & 670 \\
\hline 56 ERH 16 & 0 & 150 & 100 & 100 & 50 & 150 & 150 & 700 \\
\hline 56 ERH 17 & 0 & 120 & 100 & 100 & 50 & 60 & 60 & 490 \\
\hline 56 ERH 18 & 240 & 90 & 0 & 100 & 40 & 90 & 150 & 710 \\
\hline 56 ERH 19 & 120 & 150 & 100 & 100 & 50 & 120 & 150 & 790 \\
\hline 56 ERH 20 & 120 & 90 & 100 & 100 & 50 & 150 & 120 & 730 \\
\hline 56 ERH 21 & 60 & 120 & 100 & 100 & 50 & 120 & 60 & 610 \\
\hline 56 ERH 22 & 60 & 90 & 100 & 100 & 50 & 60 & 150 & 610 \\
\hline 56 ERH 23 & 120 & 120 & 0 & 100 & 50 & 60 & 120 & 570 \\
\hline 56 ERH 24 & 60 & 150 & 100 & 60 & 50 & 150 & 120 & 690 \\
\hline 56 ERH 25 & 120 & 90 & 100 & 100 & 50 & 30 & 60 & 550 \\
\hline 56 ERH 26 & 120 & 150 & 100 & 100 & 50 & 120 & 150 & 790 \\
\hline 56 ERH 27 & 120 & 150 & 100 & 100 & 50 & 120 & 150 & 790 \\
\hline 56 ERH 28 & 120 & 150 & 100 & 100 & 50 & 60 & 150 & 730 \\
\hline 56 ERH 29 & 60 & 150 & 100 & 100 & 50 & 30 & 150 & 640 \\
\hline 56 ERH 30 & 120 & 150 & 100 & 100 & 50 & 120 & 150 & 790 \\
\hline 56 ERH 31 & 60 & 150 & 100 & 100 & 50 & 120 & 150 & 730 \\
\hline 56 ERH 32 & 0 & 90 & 100 & 100 & 50 & 60 & 60 & 460 \\
\hline 56 ERH 33 & 0 & 90 & 100 & 100 & 50 & 60 & 60 & 460 \\
\hline 56 ERH 34 & 60 & 90 & 100 & 100 & 50 & 150 & 120 & 690 \\
\hline 56 ERH 35 & 60 & 90 & 100 & 100 & 30 & 120 & 120 & 620 \\
\hline 56 ERH 36 & 60 & 90 & 100 & 100 & 50 & 60 & 120 & 580 \\
\hline 56 ERH 37 & 60 & 90 & 100 & 100 & 40 & 120 & 120 & 630 \\
\hline 56 ERH 38 & 0 & 150 & 100 & 100 & 50 & 60 & 150 & 610 \\
\hline 56 ERH 39 & 0 & 150 & 100 & 100 & 50 & 120 & 60 & 580 \\
\hline 56 ERH 40 & 0 & 150 & 100 & 100 & 50 & 150 & 150 & 700 \\
\hline 56 ERH 41 & 60 & 90 & 100 & 100 & 50 & 30 & 60 & 490 \\
\hline 56 ERH 42 & 300 & 150 & 100 & 100 & 50 & 120 & 120 & 940 \\
\hline 56 ERH 43 & 60 & 90 & 100 & 100 & 30 & 60 & 60 & 500 \\
\hline 56 ERH 44 & 60 & 150 & 100 & 60 & 50 & 60 & 60 & 540 \\
\hline 56 ERH 45 & 0 & 90 & 100 & 60 & 30 & 60 & 150 & 490 \\
\hline 56 ERH 46 & 0 & 150 & 100 & 100 & 50 & 60 & 60 & 520 \\
\hline 56 ERH 47 & 60 & 150 & 100 & 100 & 40 & 120 & 60 & 630 \\
\hline 56 ERH 48 & 60 & 90 & 100 & 100 & 40 & 90 & 120 & 600 \\
\hline 56 ERH 49 & 0 & 150 & 100 & 100 & 50 & 90 & 120 & 610 \\
\hline $56 \mathrm{MRKZ} 01$ & 0 & 90 & 100 & 100 & 50 & 30 & 60 & 430 \\
\hline $56 \mathrm{MRKZ} 02$ & 60 & 150 & 100 & 100 & 50 & 120 & 120 & 700 \\
\hline $56 \mathrm{MRKZ} 03$ & 0 & 90 & 100 & 100 & 50 & 150 & 120 & 610 \\
\hline $56 \mathrm{MRKZ} 04$ & 0 & 150 & 100 & 100 & 50 & 120 & 150 & 670 \\
\hline $56 \mathrm{MRKZ} 05$ & 300 & 150 & 100 & 100 & 40 & 30 & 60 & 780 \\
\hline
\end{tabular}

"MA: Meyve ağırlığı, MŞİ: Meyve şekil indeksi, KÇ: Kabuk çatlaması, KSD: Kabuk soyulma durumu, OA: Ostiolum açıklığı, SÇKM: Suda çözülebilir kuru madde, TEA: Titre edilebilir asitlik

\section{Sonuç ve Öneriler}

Siirt kültür incir varyasyonlarının yanında, yüksek bir şekilde yabani incir form, varyasyon ve dağılımına sahiptir.
Çalışma sonuçlarına göre; "56 ERH 04" genotipi ile "56 ERH 39” (Rej1k) genotipi, özellikle Türkiye kurutmalık incir sektöründe ön planda olan sarılop çeşidi ile benzer niteliklere sahip oldukları 
düşünüldüğünden kurutmalık incir olarak değerlendirilebileceği kanaatine varılmıştır.

Diğer taraftan, gerek arazi koşullarında gerekse laboratuvar şartlarında elde edilen verilerden yola çıkılarak bir değerlendirme yapılacak olursa, özellikle yöresel isimleri Tefari, Teğte, Behtani ve Becani olarak anılan bazı genotiplerin sofralık incir piyasasında önemli yeri olan Bursa Siyahı çeşidi ile birçok özelliği bakımından benzer kalitede oldukları söylenebilir.

Siirt yöresinde özellikleri incelenen incir genotiplerinin bölgede yetiştiriciliğinin yaygınlaştırılması, daha bilinçli ve planlı bir yetiştiriciliğinin yapılabilmesi için bölge şartlarına uygun genotipler/mahalli çeşitler belirlenmelidir. Belirlenen bu çeşitler ile üretim yapılmalı, geleneksel karışı meyve bahçeciliğinin yerine planlı kapama incir bahçeleri tesis edilmelidir.

Ümitvar olarak değerlendirilen söz konusu genotiplerin klonlarının alınarak, çoğaltılması ve yörede yaygınlaştırılması, hem bölge hem de ülke ekonomisine katkı sağlayacaktır.

Günümüzde incir 1slah çalıșmalarının hedefi özellikle kurutmalık incirlerde sarı kabuk rengi, beyaz meyve eti; sofralı incirlerde ise iri meyve, taşınmaya dayanıklı kabuk ve partenokarp özelliklerini taşıyan genotipler elde etmek olduğu göz önüne alınırsa, bu çalışmanın sonuçları itibarı ile ülke ve bölge yetiştiriciliğine katkıda bulunacağ düşünülmektedir.

\section{Kaynaklar}

Aksoy, U., 1991. Descriptors for Fig (Ficus carica L. and related Ficus sp.) Ege Univcity, Faculty of Agriculture Departmant of Horticulture, Izmir, Turkey.

Aksoy, U., Anaç, D., 1995. Factors affecting quality of fresh and dried fig fruits. Acta Horticulturae, 368: 763-766.

Aksoy, U., Seferoğlu, G., Misırlı, A., Kara, S., Şahin, N., Bülbül, S., Düzbastılar, M., 1992. Ege Bölgesi koşullarına uygun sofralık incir çeşit seleksiyonu. Türkiye I. Bahçe Bitkileri Kongresi, 13-16 Ekim, İzmir, s. 545-548.

Anonim, 2019a. Bitkisel Üretim İstatistikleri. Türkiye İstatistik Kurumu, (www.tuik.gov.tr), (Erişim tarihi: 23.05.2019).

Anonim, 2019b. Türkiye'nin Biyoçeşitliliği: Genetik Kaynakların Sürdürülebilir Tarım ve Gıda Sistemlerine Katkıs1. Birlesmis Milletler Gida ve Tarım Örgütü (http://www.fao.org/3/ca1517tr/ CA1517TR.pdf), Ankara.

Anonymous, 2003. Descriptors for figs. International Plant Genetic Reseources Institute IPGRI, Rome, Italy, and International Centre for Advanced
Mediterranean Agronomic Studies (CIHEAM), Paris, France.

Anonymous, 2017. FAOSTAT. (http://www.fao.org/ faostat/en/\#data/QC/visualize), (Erişim tarihi: 10.07. 2017).

Arendt, H.K., 1972. Fig Cultivars. The State Nikita Botanical Gardens Yalta. Proc.Vol. LVI 56: 23-91.

Bostan, S.Z., İslam, A., 1999. Vakfikebir'de yetiştirilen önemli mahalli incir çeşitlerinin pomolojik özellikleri. Türkiye III. Bahçe Bitkileri Kongresi, 1417 Eylül, Ankara, s. 751-755.

Can, H.Z., 1993. Bazı seçilmiş sofralık incir çeşitlerinin Ege Bölgesi koşullarında özelliklerinin belirlenmesi üzerinde araştırmalar. Yüksek lisans tezi (Basılmamış), Ege Üniversitesi, Fen Bilimleri Enstitüsü, İzmir.

Cebeci, E., 1993. Çukurova ve Ege incir klon ve çeşitlerinde meyve doğuşları, çiçek organlarının gelişimi ve döllenme biyolojileri üzerinde çalışmalar. Yüksek lisans tezi (Basılmamıș), Çukurova Üniversitesi, Fen Bilimleri Enstitüsü, Adana.

Çalışkan, O., Polat, A.A., 2007. Fruit characteristics of table fig (Ficus carica) cultivars in subtropical climate conditions of the Mediterranean region. New Zealand Journal of Crop and Horticultural Science, 36: 107-115.

Çalışkan, O., Polat, A.A., 2011. Phytochemical and antioxidant properties of selected fig (Ficus carica L.) accessions from the eastern Mediterranean region of Turkey. Science Horticulture, 128: 473-478.

Eroğlu, A.Ş., 1982. İncir Seleksiyonu. İncir Araştırmaları Projesi, Erbeyli Zirai Araştırma Enstitüsü Müdürlüğü, Aydın.

Gözlekçi, Ş., Ersoy, N., İmamgiller, B., ve Yazıcı, K., 1999. Bazı incir (Ficus carica L.) çeşitlerinin Antalya ekolojik koşullarına adaptasyonu üzerinde araștırmalar. Türkiye 3. Ulusal Bahçe Bitkileri Kongresi, 14-17 Eylül, Ankara, s. 36-40.

Hepaksoy, S., Aksoy, U., Şahin, N., 2004. Bazı incir çeşitlerinin morfolojik ve moleküler yöntemlerle tanımlanması. TUBİTAK-TARP 2574-3, İzmir.

Ilgın, M., 1995. Kahramanmaraş Bölgesi'nde incir seleksiyonu ve selekte edilen bazı önemli tiplerin meyve doğuşları ve döllenme biyolojileri üzerinde çalışmalar. Doktora tezi (Basılmamış), Çukurova Üniversitesi, Fen Bilimleri Enstitüsü, Adana.

Ilgın, M., Küden, A.B., 1997. Table fig selection study in the Kahramanmaraş province of Turkey. Acta Horticulture, 441: 351-358.

Karaçalı, İ., 1990. Bahçe Ürünlerinin Muhafazası ve Pazarlanması. Ege Üniversitesi Ziraat Fakültesi Yayın1, No: 494, İzmir.

Karadeniz, T., 2003. A study on some fruit characteristics and propagations of these by hardwood cutting of local fig cultivars grownin Ordu. Acta Horticulturae, 605: 107-112.

Kaşka, N., Küden, A.B., Küden, A., Çetiner, S., 1990. Ege Bölgesi incirleri ile Çukurova Bölgesi'nden selekte edilen incirlerin Adana'ya adaptasyonu 
üzerinde çalışmalar. Çukurova Üniversitesi Ziraat Fakültesi Dergisi, 5(4): 77-86.

Khadivi-Khub, A., Anjam, K., 2014. Characterization and evaluation of male fig (caprifig) accessionsin Iran. Plant Systematics and Evolution, DOI 10.1007/ s00606-014-1038-4.

Koyuncu, M.A., 1998. A study on some fruit characteristics in local fig cultivars grown in Hilvan (Urfa, Southern Turkey). Acta Horticulturae, 480: 83-85.

Küden, A.B., Tanrıver, E., 1997. Plant genetic resources and selection studies on figs in the East Mediterranean and South East Anatolia Regions. First International Symposium on Fig, 24-28 June, İzmit, Turkey, s. 49-54.
Küden, A.B., Tanrıver, E., Kaşka, N., 1995. Çukurova Bölgesi'ne önerilebilecek bazı incir çeşit ve klonlarının saptanması. Türkiye 2. Ulusal Bahçe Bitkileri Kongresi, 3-6 Ekim, Adana, s. 663-667.

Özbek, S., 1978. Özel Meyvecilik. Cukurova Üniversitesi Ziraat Fakültesi Yayınları No: 128, Ders Kitabı: 11, Adana.

Özeker, E., İsfendiyaroğlu, M., 1998. Evaluation of table fig cultivars in çeşme peninsula. Acta Horticulturae, 480: $55-60$

Özkaya, M., 1997. Antakya yöresinde yetiştirilmekte olan incirlerde seleksiyon çalıșmaları. Yüksek lisans tezi (Basılmamış), Mustafa Kemal Üniversitesi, Fen Bilimleri Enstitüsü, Antakya.

Vinson, J.A., 1999. The functional food properties of figs. Cereal Food World, 4: 82-87. 